\title{
Positive surgical margin is associated with biochemical recurrence risk following radical prostatectomy: a meta-analysis from high-quality retrospective cohort studies
}

\author{
Lijin Zhang ${ }^{*}$, Bin Wu, Zhenlei Zha ${ }^{\dagger}, \mathrm{Hu} \mathrm{Zhao}^{\dagger}$, Yuefang Jiang ${ }^{\dagger}$ and Jun Yuan
}

\begin{abstract}
Background and purpose: Although numerous studies have shown that positive surgical margin (PSM) is linked to biochemical recurrence $(B C R)$ in prostate cancer $(\mathrm{PCa})$, the research results have been inconsistent. This study aimed to explore the association between PSM and BCR in patients with PCa following radical prostatectomy (RP).

Materials and methods: In accordance with the guidelines of the Preferred Reporting Items for Systematic Reviews and Meta-Analyses (PRISMA), PubMed, EMBASE and Wan Fang databases were searched for eligible studies from inception to November 2017. The Newcastle-Ottawa Scale was used to assess the risk of bias of the included studies. Meta-analysis was performed by using Stata 12.0. Combined hazard ratios (HRs) and their corresponding 95\% confidence intervals (Cls) were calculated using random-effects or fixed-effects models.
\end{abstract}

Results: Ultimately, 41 retrospective cohort studies of high quality that met the eligibility criteria, comprising 37,928 patients (94-3294 per study), were included in this meta-analysis. The results showed that PSM was associated with higher $\mathrm{BCR}$ risk in both univariate analysis (pooled $\mathrm{HR}=1.56 ; 95 \% \mathrm{Cl} 1.46,1.66 ; p<0.001$ ) and multivariate analysis (pooled HR=1.35; 95\% Cl 1.27, 1.43; $p<0.001$ ). Moreover, no potential publication bias was observed among the included studies in univariate analysis ( $p$-Begg $=0.971$ ) and multivariate analysis ( $p$-Begg $=0.401$ ).

Conclusions: Our meta-analysis demonstrated that PSM is associated with a higher risk of BCR in PCa following RP and could serve as an independent prognostic factor in patients with PCa.

Keywords: Positive surgical margin, Prostate cancer, Radical prostatectomy, Biochemical recurrence, Meta-analysis

\section{Background}

Prostate cancer $(\mathrm{PCa})$ is the most diagnosed malignancy and the second leading cause of cancer-related deaths among men in Western countries [1]. Radical prostatectomy (RP) has been shown to have a cancer-specific survival benefit for men with clinically localised PCa [2]. Although many patients are disease-free after surgery, nearly $30 \%$ [3] of patients still continue to experience biochemical recurrence (BCR). Defined as a detectable prostate-specific antigen (PSA) level following RP in the absence of clinical progression, $\mathrm{BCR}$ is the most common pattern of disease relapse [4]. Patients

\footnotetext{
*Correspondence: stzlj913729553@163.com

${ }^{\dagger}$ Zhenlei Zha, Hu Zhao and Yuefang Jiang contributed equally to this work. Departments of Urology, Affiliated Jiang-yin Hospital of the Southeast University Medical College, Jiang-yin 214400, China
}

with $\mathrm{BCR}$ have a considerably worse prognosis, often develop metastasis, and can die of the disease [3, 4]. Therefore, identifying prognostic predictors of $\mathrm{BCR}$ after RP to assist clinicians in predicting outcomes for decision making is required.

Numerous nomograms including pathological tumour stage [5], Gleason's score [6], seminal vesicle invasion [7], and lymphatic invasion [8] have been developed to predict subsequent risk of BCR after RP. Unfortunately, because the collective prognostic value of these factors is unsatisfactory, better biomarkers are urgently needed. Positive surgical margin (PSM) is defined as the histological presence of cancer cells at the inked margin on the RP specimen [9]. Although PSM is frequently reported in radical prostatectomy series, their clinical relevance remains uncertain despite extensive investigation. A number of studies have

(c) The Author(s). 2018 Open Access This article is distributed under the terms of the Creative Commons Attribution 4.0 International License (http://creativecommons.org/licenses/by/4.0/), which permits unrestricted use, distribution, and 
Table 1 Primary characteristics of the included studies

\begin{tabular}{|c|c|c|c|c|c|c|c|c|}
\hline Author & Year & Country & $\begin{array}{l}\text { No. of } \\
\text { patients }\end{array}$ & $\begin{array}{l}\text { Recruitment } \\
\text { period }\end{array}$ & $\begin{array}{l}\text { Age } \\
\text { (years) }\end{array}$ & $\begin{array}{l}\text { p-PSA } \\
(\mathrm{ng} / \mathrm{ml})\end{array}$ & $\begin{array}{l}\text { Follow-up } \\
\text { (months) }\end{array}$ & $\begin{array}{l}\text { Surgical } \\
\text { approach }\end{array}$ \\
\hline Wettstein et al. [35] & 2017 & Switzerland & 371 & $2008-2015$ & $\begin{array}{l}\text { Median (range) } \\
63(41-78)\end{array}$ & $\begin{array}{l}\text { Median (range) } \\
6.79(0.43-81.4)\end{array}$ & $\begin{array}{l}\text { Median (range) } \\
28(1-64)\end{array}$ & $\mathrm{NA}$ \\
\hline Xun et al. [6] & 2017 & China & 172 & 2003-2014 & $\begin{array}{l}\text { Median (IQR) } \\
68(62-72)\end{array}$ & $\begin{array}{l}\text { Median (IQR) } \\
16.1(10.9-28.3)\end{array}$ & $\begin{array}{l}\text { Median (IQR) } \\
46.4(33.4-62.4)\end{array}$ & NA \\
\hline Meyer et al. [36] & 2017 & Germany & 903 & 1992-2005 & $\begin{array}{l}\text { Median (IQR) } \\
63(59-66)\end{array}$ & $\begin{array}{l}\text { Median (IQR) } \\
6.4(4.6-9.0)\end{array}$ & $\begin{array}{l}\text { Median (IQR) } \\
133(97-157)\end{array}$ & NA \\
\hline Gandaglia et al. [37] & 2017 & Multi-centred & 94 & $2011-2015$ & $\begin{array}{l}\text { Median (IQR) } \\
64.3(57.1-68.9)\end{array}$ & $\begin{array}{l}\text { Median (IQR) } \\
9.7(5.1-17.5)\end{array}$ & $\begin{array}{l}\text { Median (IQR) } \\
23.5(18.7-27.3)\end{array}$ & Robot-assisted RP \\
\hline Shangguan et al. [33] & 2016 & China & 172 & 2003-2014 & $\begin{array}{l}\text { Median (range) } \\
68(62-72)\end{array}$ & $\begin{array}{l}\text { Median (range) } \\
16.1(10.9-28.3)\end{array}$ & $\begin{array}{l}\text { Median (IQR) } \\
46.4(33.4-62.4)\end{array}$ & Open and laparoscopic RP \\
\hline Zhang et al. [34] & 2016 & China & 168 & $2006-2011$ & $\begin{array}{l}\text { Median (range) } \\
69(53-85)\end{array}$ & $\begin{array}{l}\text { Median (range) } \\
13.31(4.59-36.12)\end{array}$ & $\begin{array}{l}\text { Median (range) } \\
68 \text { (7-98) }\end{array}$ & Laparoscopic RP \\
\hline Simon et al. [12] & 2016 & Multi-centres & 411 & $2001-2013$ & $\begin{array}{l}\text { Mean } \pm \text { SD } \\
61 \pm 6.1\end{array}$ & NA & $\begin{array}{l}\text { Median } \\
63\end{array}$ & NA \\
\hline Sevcenco et al. [38] & 2016 & Multi-centres & 7205 & 2000-2011 & $\begin{array}{l}\text { Median (IQR) } \\
61(57-66)\end{array}$ & $\begin{array}{l}\text { Median (IQR) } \\
6(4-9)\end{array}$ & $\begin{array}{l}\text { Median (IQR) } \\
27(19-48)\end{array}$ & NA \\
\hline Pagano et al. [20] & 2016 & USA & 180 & 1990-2011 & $\begin{array}{l}\text { Median (range) } \\
63.7(58.8-67.6)\end{array}$ & $\begin{array}{l}\text { Median (range) } \\
9.1(6.3-17.1)\end{array}$ & $\begin{array}{l}\text { Median (range) } \\
26.7(8.8-66)\end{array}$ & NA \\
\hline Moschini et al. [39] & 2016 & USA & 1011 & 1987-2012 & NA & $\begin{array}{l}\text { Median } \\
12.0\end{array}$ & $\begin{array}{l}\text { Median } \\
211.2\end{array}$ & NA \\
\hline Mortezavi et al. [40] & 2016 & Switzerland & 100 & 1999-2007 & $\begin{array}{l}\text { Mean } \pm \text { SD } \\
63.5 \pm 6.5\end{array}$ & $\begin{array}{l}\text { Mean } \pm \text { SD } \\
9.6 \pm 8.3\end{array}$ & $\begin{array}{l}\text { Median (range) } \\
126(60-176)\end{array}$ & Laparoscopic RP \\
\hline Mao et al. [41] & 2016 & China & 106 & 2008-2009 & $\begin{array}{l}\text { Mean (range) } \\
68.1(48-83)\end{array}$ & $\begin{array}{l}\text { Mean (range) } \\
25.1(3.1-104.3)\end{array}$ & $\begin{array}{l}\text { Median (range) } \\
69(8-84)\end{array}$ & Laparoscopic RP \\
\hline Whalen et al. [29] & 2015 & USA & 609 & 2005-2011 & $\begin{array}{l}\text { Mean } \pm \text { SD } \\
61.2 \pm 7.3\end{array}$ & $\begin{array}{l}\text { Mean } \pm \text { SD } \\
6.8 \pm 6.3\end{array}$ & $\begin{array}{l}\text { Median (range) } \\
20.5(1-80)\end{array}$ & NA \\
\hline Song et al. [42] & 2015 & Korea & 2137 & 1988-2011 & $\begin{array}{l}\text { Median (IQR) } \\
67(63-71)\end{array}$ & $\begin{array}{l}\text { Median (IQR) } \\
6.9(4.7-11.2)\end{array}$ & $\begin{array}{l}\text { Mean (range) } \\
39.4(8-1834)\end{array}$ & NA \\
\hline Reeves et al. [43] & 2015 & Australia & 1479 & 2005-2012 & $\begin{array}{l}\text { Median } \\
62\end{array}$ & NA & $\begin{array}{l}\text { Median } \\
14\end{array}$ & NA \\
\hline Hashimoto et al. [5] & 2015 & Japan & 837 & 2006-2013 & $\begin{array}{l}\text { Median (range) } \\
65(39-78)\end{array}$ & $\begin{array}{l}\text { Median (range) } \\
6.9(3-47.4)\end{array}$ & $\begin{array}{l}\text { Median (range) } \\
20.5(1.3-91.3)\end{array}$ & Robot-assisted RP \\
\hline Alvin et al. [44] & 2015 & Singapore & 725 & 2003-2013 & $\begin{array}{l}\text { Median (range) } \\
62(37-79)\end{array}$ & $\begin{array}{l}\text { Median (range) } \\
7.9(0.79-72.9)\end{array}$ & $\begin{array}{l}\text { Mean (range) } \\
28.5(6-116)\end{array}$ & Robot-assisted RP \\
\hline Touijer et al. [13] & 2014 & USA & 369 & 1988-2010 & $\begin{array}{l}\text { Median (IQR) } \\
62(57-66)\end{array}$ & $\begin{array}{l}\text { Median (IQR) } \\
8(5-15)\end{array}$ & $\begin{array}{l}\text { Median } \\
48\end{array}$ & NA \\
\hline Ritch et al. [45] & 2014 & USA & 979 & 2003-2009 & $\begin{array}{l}\text { Median } \\
62\end{array}$ & NA & $\begin{array}{l}\text { Median } \\
47\end{array}$ & $\begin{array}{l}\text { Open and robot- } \\
\text { assisted RP }\end{array}$ \\
\hline Kang et al. [21] & 2014 & Korea & 3034 & 2004-2011 & $\begin{array}{l}\text { Mean } \pm \text { SD } \\
65.9 \pm 6.6\end{array}$ & $\begin{array}{l}\text { Mean } \pm \text { SD } \\
11.6 \pm 12.2\end{array}$ & $\begin{array}{l}\text { Median } \\
47\end{array}$ & NA \\
\hline Fairey et al. [14] & 2014 & USA & 229 & 1987-2008 & $\begin{array}{l}\text { Median (range) } \\
65(41-83)\end{array}$ & NA & $\begin{array}{l}\text { Median (range) } \\
174(2.4-253.2)\end{array}$ & NA \\
\hline Turker et al. [46] & 2013 & Turkey & 331 & 1993-2009 & $\begin{array}{l}\text { Mean } \pm \text { SD } \\
62.79 \pm 6.4\end{array}$ & $\begin{array}{l}\text { Mean } \pm \text { SD } \\
11.1 \pm 10.5\end{array}$ & $\begin{array}{l}\text { Mean } \pm \text { SD } \\
29.7 \pm 33.2\end{array}$ & NA \\
\hline Sammon et al. [10] & 2013 & USA & 794 & 1993-2010 & $\begin{array}{l}\text { Mean } \pm \text { SD } \\
63.4 \pm 8.1\end{array}$ & $\begin{array}{l}\text { Mean } \pm \text { SD } \\
5.6 \pm 3.6\end{array}$ & $\begin{array}{l}\text { Median (IQR) } \\
\text { 26.4(12.2-54.6) }\end{array}$ & NA \\
\hline Chen et al. [30] & 2013 & China & 152 & 2004-2011 & NA & NA & $\begin{array}{l}\text { Median (range) } \\
48(12-87)\end{array}$ & Laparoscopic RP \\
\hline Sooriakumaran et al. [11] & 2012 & Sweden & 944 & $2002-2006$ & $\begin{array}{l}\text { Median (IQR) } \\
62.2(58.2-65.8)\end{array}$ & $\begin{array}{l}\text { Median (IQR) } \\
6.4(4.8-9.0)\end{array}$ & $\begin{array}{l}\text { Median (IQR) } \\
75.6(67.2-86.4)\end{array}$ & Robot-assisted RP \\
\hline Lu et al. [31] & 2012 & China & 894 & 1993-1999 & $\begin{array}{l}\text { Median (IQR) } \\
62(57-66)\end{array}$ & $\begin{array}{l}\text { Median (IQR) } \\
6.0(4.5-8.6)\end{array}$ & $\begin{array}{l}\text { Median (IQR) } \\
9.9(6.1-11.3)\end{array}$ & NA \\
\hline Iremashvili et al. [47] & 2012 & USA & 1444 & $2003-2010$ & Mean (range) & Mean (range) & Median (range) & \\
\hline
\end{tabular}


Table 1 Primary characteristics of the included studies (Continued)

\begin{tabular}{|c|c|c|c|c|c|c|c|c|}
\hline Author & Year & Country & $\begin{array}{l}\text { No. of } \\
\text { patients }\end{array}$ & $\begin{array}{l}\text { Recruitment } \\
\text { period }\end{array}$ & $\begin{array}{l}\text { Age } \\
\text { (years) }\end{array}$ & $\begin{array}{l}\text { p-PSA } \\
\text { (ng/ml) }\end{array}$ & $\begin{array}{l}\text { Follow-up } \\
\text { (months) }\end{array}$ & $\begin{array}{l}\text { Surgical } \\
\text { approach }\end{array}$ \\
\hline & & & & & $61.3(56-66.3)$ & $5.7(4.5-8.0)$ & $43.2(3-216)$ & $\begin{array}{l}\text { Open and } \\
\text { robot-assisted RP }\end{array}$ \\
\hline Connolly et al. [48] & 2012 & Australia & 160 & 1988-1997 & $\begin{array}{l}\text { Mean } \pm S D \\
63.1 \pm 6.3\end{array}$ & $\begin{array}{l}\text { Median (IQR) } \\
9.95(6.0-21.4)\end{array}$ & $\begin{array}{l}\text { Median (IQR) } \\
26.2(5.5-37.3)\end{array}$ & Robot-assisted RP \\
\hline Busch et al. [49] & 2012 & Germany & 1845 & 1999-2007 & $\begin{array}{l}\text { Mean } \pm \text { SD } \\
62.0 \pm 5.9\end{array}$ & $\begin{array}{l}\text { Median (range) } \\
26.3(17.0-42.1)\end{array}$ & $\begin{array}{l}\text { Median (range) } \\
56(0-35)\end{array}$ & Laparoscopic RP \\
\hline Berge et al. [50] & 2012 & Norway & 577 & $2002-2008$ & $\begin{array}{l}\text { Mean (range) } \\
61.5(42-76)\end{array}$ & $\begin{array}{l}\text { Mean (range) } \\
8.4(0.3-31)\end{array}$ & $\begin{array}{l}\text { Median (range) } \\
36(3-72)\end{array}$ & Laparoscopic RP \\
\hline Lee et al. [51] & 2011 & Korea & 1000 & 2003-2009 & $\begin{array}{l}\text { Median (range) } \\
66 \text { (37-82) }\end{array}$ & $\begin{array}{l}\text { Median (range) } \\
7.8(0.1-261.8)\end{array}$ & $\begin{array}{l}\text { Mean } \\
39.4\end{array}$ & NA \\
\hline Alenda et al. [23] & 2011 & France & 1248 & 1998-2008 & $\begin{array}{l}\text { Mean (range) } \\
63(44-78)\end{array}$ & $\begin{array}{l}\text { Mean (range) } \\
10.9(0.9-134)\end{array}$ & $\begin{array}{l}\text { Median } \\
23.4\end{array}$ & NA \\
\hline Fukuhara et al. [52] & 2010 & Japan & 364 & 2000-2009 & $\begin{array}{l}\text { Median (range) } \\
66(52-78)\end{array}$ & $\begin{array}{l}\text { Median (range) } \\
8.1(1.7-77.7)\end{array}$ & $\begin{array}{l}\text { Median (range) } \\
33(10-109)\end{array}$ & NA \\
\hline Cho et al. [53] & 2010 & Korea & 171 & 2005-2009 & $\begin{array}{l}\text { Mean (range) } \\
64.4(49-80)\end{array}$ & NA & $\begin{array}{l}\text { Mean (range) } \\
23.3(2-51)\end{array}$ & NA \\
\hline Alkhateeb et al. [26] & 2010 & Canada & 1268 & 1992-2008 & $\begin{array}{l}\text { Mean } \pm S D \\
62.0 \pm 6.6\end{array}$ & $\begin{array}{l}\text { Median (range) } \\
6.2(0.1-65.9)\end{array}$ & $\begin{array}{l}\text { Mean (range) } \\
78.1(3-192)\end{array}$ & NA \\
\hline Jeon et al. [54] & 2009 & Korea & 237 & 1995-2004 & $\begin{array}{l}\text { Mean (range) } \\
64.5 \text { (44-86) }\end{array}$ & $\begin{array}{l}\text { Mean (range) } \\
11.5(0.2-98)\end{array}$ & $\begin{array}{l}\text { Median (range) } \\
21.6(2-88)\end{array}$ & NA \\
\hline Schroeck et al. [55] & 2008 & USA & 3194 & 1988-2007 & $\begin{array}{l}\text { Median (IQR) } \\
62.6(57.2-67.9)\end{array}$ & $\begin{array}{l}\text { Median (IQR) } \\
6.3(4.5-9.6)\end{array}$ & $\begin{array}{l}\text { Median } \\
31.2\end{array}$ & NA \\
\hline Pavlovich et al. [56] & 2008 & USA & 508 & 2001-2005 & $\begin{array}{l}\text { Mean } \pm \text { SD } \\
57.6 \pm 6.7\end{array}$ & $\begin{array}{l}\text { Mean (range) } \\
6.0(0.3-27)\end{array}$ & $\begin{array}{l}\text { Median (range) } \\
12(2-52)\end{array}$ & Laparoscopic RP \\
\hline Hong et al. [57] & 2008 & Korea & 372 & 2003-2007 & $\begin{array}{l}\text { Mean (range) } \\
64.2(37-72)\end{array}$ & $\begin{array}{l}\text { Mean (range) } \\
8.7(0.2-104.2)\end{array}$ & NA & NA \\
\hline Cheng et al. [8] & 2005 & Indiana & 504 & 1990-1998 & $\begin{array}{l}\text { Mean (range) } \\
62(34-80)\end{array}$ & NA & $\begin{array}{l}\text { Mean (range) } \\
44(1.5-144)\end{array}$ & NA \\
\hline Shariat et al. [58] & 2004 & USA & 630 & 1994-2002 & $\begin{array}{l}\text { Median (range) } \\
60.9(40-75)\end{array}$ & $\begin{array}{l}\text { Mean (range) } \\
6.1 \text { (0.1-99) }\end{array}$ & $\begin{array}{l}\text { Median (range) } \\
21.4(1-101.3)\end{array}$ & NA \\
\hline
\end{tabular}

p-PSA preoperative prostate-specific antigen, $S D$ standard deviation, IQR interquartile range, NA data not applicable

demonstrated an association between PSM and BCR $[5,10,11]$, while others have observed insignificant or even contrary correlations [12-14].

Previously, Yossepowitch [15] systematically reviewed related studies on PSM reporting survival of surgical treatment for patients with PCa. These studies suggested that PSM in PCa should be considered an adverse oncological outcome. Nevertheless, a meta-analysis was not performed because of low-quality evidence and potential risks of bias. A meta-analysis utilises statistical methods to contrast and combine results from multiple studies, increasing the statistical power and reproducibility compared with individual studies [16]. Hence, to obtain the most conclusive results, we conducted a meta-analysis with high-quality retrospective cohort studies to assess the prognostic value of PSM in BCR.

\section{Methods}

\section{Literature search}

This meta-analysis was conducted in accordance with the Preferred Reporting Items for Systematic Reviews and Meta-Analyses (PRISMA) guidelines. A comprehensive search of the literature in PubMed, EMBASE, and Wan Fang databases up to November 2017 was performed using a combined text and MeSH heading search strategy with the following terms: ("prostate cancer" or "prostate AND neoplasms") and ("radical prostatectomy") and ("positive surgical margin") and ("biochemical recurrence" OR "biochemical failure"). In addition, reference lists in the recent reviews, meta-analysis, and included articles were manually searched to identify related articles. The language of the publications was limited to English and Chinese.

\section{Inclusion and exclusion criteria}

We defined the inclusion and exclusion criteria for study selection at the initiation of the search. The following inclusion criteria were used: (1) included definitive diagnosis of PCa and PSM assessed by pathologists; (2) all patients underwent RP treatment; (3) BCR after RP was 
Table 2 Tumour characteristics of the included studies

\begin{tabular}{|c|c|c|c|c|c|c|}
\hline Author & $\begin{array}{l}\text { Specimen } \\
\mathrm{GS} \leqq 7 />7\end{array}$ & Staging system & $\begin{array}{l}\text { T stage } \\
1-2 / 3-4\end{array}$ & $\mathrm{SM}+/ \mathrm{SM}_{-}$ & No. of $\mathrm{BCR}(\%)$ & Definition of $B C R$ \\
\hline Wettstein et al. [35] & $292 / 79$ & WHO/ISUP 2016 & $263 / 108$ & $133 / 238$ & $49(13.2 \%)$ & Rising and verified PSA levels $>0.1 \mathrm{ng} / \mathrm{ml}$ \\
\hline Xun et al. [6] & $131 / 41$ & TNM 2002 & NA & $62 / 110$ & $80(46.5 \%)$ & The date of the first PSA elevated to $0.2 \mathrm{ng} / \mathrm{ml}$ \\
\hline Meyer et al. [36] & $879 / 24$ & TNM 2002 & $903 / 0$ & $37 / 206$ & $137(15.2 \%)$ & PSA level of $\geqq 0.2 \mathrm{ng} / \mathrm{ml}$ and rising after RP \\
\hline Gandaglia et al. [37] & $55 / 39$ & TNM 2002 & $22 / 72$ & $30 / 64$ & $24(25.5 \%)$ & Two consecutive increases in PSA $\geqq 0.2 \mathrm{ng} / \mathrm{ml}$ \\
\hline Shangguan et al. [33] & $131 / 41$ & NA & NA & $62 / 110$ & NA & Two consecutive increases in PSA $\geqq 0.2 \mathrm{ng} / \mathrm{ml}$ \\
\hline Zhang et al. [34] & $136 / 32$ & TNM 2012 & NA & $30 / 138$ & NA & First PSA elevated to $0.2 \mathrm{ng} / \mathrm{ml}$ \\
\hline Simon et al. [12] & $368 / 43$ & NA & NA & $353 / 58$ & $70(17 \%)$ & $\begin{array}{l}\text { Single PSA concentration of }>0.2 \text {, } \\
\text { two concentrations at } 0.2 \mathrm{ng} / \mathrm{ml}\end{array}$ \\
\hline Sevcenco et al. [38] & $6645 / 560$ & TNM 2009 & NA & $6137 / 1074$ & $798(11.1 \%)$ & Two consecutive increases in PSA $\geqq 0.2 \mathrm{ng} / \mathrm{ml}$ \\
\hline Pagano et al. [20] & $90 / 90$ & TNM 2002 & NA & $74 / 106$ & $120(66.5 \%)$ & Two postoperative PSA values of $\geqq 0.2 \mathrm{ng} / \mathrm{ml}$ \\
\hline Moschini et al. [39] & $647 / 364$ & NA & $355 / 657$ & $566 / 445$ & $697(69 \%)$ & PSA $0.4 \mathrm{ng} / \mathrm{ml}$ or greater \\
\hline Mortezavi et al. [40] & $86 / 14$ & NA & $79 / 21$ & $25 / 75$ & $12(12 \%)$ & Two consecutive increases in PSA $\geqq 0.2 \mathrm{ng} / \mathrm{ml}$ \\
\hline Mao et al. [41] & $78 / 28$ & TNM 2002 & $63 / 43$ & 20/86 & $31(29.2 \%)$ & Two consecutive increases in PSA $\geqq 0.2 \mathrm{ng} / \mathrm{ml}$ \\
\hline Whalen et al. [29] & $516 / 93$ & TNM 1997 & $435 / 174$ & $483 / 126$ & $73(12 \%)$ & Two consecutive increases in PSA $\geqq 0.2 \mathrm{ng} / \mathrm{ml}$ \\
\hline Song et al. [42] & $1722 / 415$ & NA & $1899 / 248$ & $2132 / 13,433$ & $466(21.8 \%)$ & Greater than $0.2 \mathrm{ng} / \mathrm{ml}$ \\
\hline Reeves et al. [43] & $1306 / 142$ & NA & $1042 / 454$ & $390 / 1089$ & $238(20.5 \%)$ & Greater than $0.2 \mathrm{ng} / \mathrm{ml}$ \\
\hline Hashimoto et al. [5] & $634 / 373$ & WHO 2004 & $677 / 160$ & $243 / 594$ & $102(12.2 \%)$ & Two consecutive increases in PSA $\geqq 0.2 \mathrm{ng} / \mathrm{ml}$ \\
\hline Alvin et al. [44] & $663 / 58$ & TNM 2010 & $497 / 228$ & $311 / 414$ & $104(14 \%)$ & Two consecutive increases in PSA $\geqq 0.2 \mathrm{ng} / \mathrm{ml}$ \\
\hline Touijer et al. [13] & 184/185 & TNM 2010 & $46 / 323$ & $138 / 231$ & $201(54 \%)$ & PSA $\geqq 0.1 \mathrm{ng} / \mathrm{ml}$ with confirmatory rise \\
\hline Ritch et al. [45] & 783/196 & TNM 2002 & $955 / 24$ & $335 / 644$ & $317(32.4 \%)$ & Greater than $0.2 \mathrm{ng} / \mathrm{ml}$ \\
\hline Kang et al. [21] & $2575 / 459$ & TNM 2009 & NA & $974 / 2060$ & NA & A serum PSA value of $0.4 \mathrm{ng} / \mathrm{ml}$ or greater after RP \\
\hline Fairey et al. [14] & $133 / 96$ & TNM 2002 & $0 / 229$ & $105 / 124$ & $83(36.2 \%)$ & $\begin{array}{l}\text { Detectable PSA (ng/ml) followed by two } \\
\text { consecutive confirmatory (1988-1994: PSA } \geqq 0.3 ; \\
\text { 1995-2005: PSA } \geqq 0.05 ; \text { 2006-present: PSA } \geqq 0.03 \text { ) }\end{array}$ \\
\hline Turker et al. [46] & $167 / 164$ & TNM 1994 & NA & $80 / 251$ & $70(21 \%)$ & $\begin{array}{l}\text { Higher than } 0.2 \mathrm{ng} / \mathrm{ml} \text { on } 2 \text { separate } \\
\text { measurements } 1 \text { month apart }\end{array}$ \\
\hline Sammon et al. [10] & $760 / 34$ & AJCC 2002 & $592 / 202$ & $162 / 632$ & $107(13.5 \%)$ & Two consecutive increases in PSA $\geqq 0.2 \mathrm{ng} / \mathrm{ml}$ \\
\hline Chen et al. [30] & $109 / 43$ & NA & $0 / 152$ & $27 / 125$ & $80(52.6 \%)$ & Two consecutive increases in PSA $\geqq 0.2 \mathrm{ng} / \mathrm{ml}$ \\
\hline Sooriakumaran et al. [11] & $900 / 44$ & NA & $651 / 230$ & 194/704 & $135(15.2 \%)$ & Greater than $0.2 \mathrm{ng} / \mathrm{ml}$ \\
\hline Lu et al. [31] & $796 / 98$ & TNM 2010 & 703/191 & $250 / 644$ & $277(31 \%)$ & $P S A \geqq 0.1 \mathrm{ng} / \mathrm{ml}$ with confirmatory rise \\
\hline Iremashvili et al. [47] & $1286 / 258$ & NA & NA & $479 / 965$ & $210(15 \%)$ & Greater than $0.2 \mathrm{ng} / \mathrm{ml}$ \\
\hline Connolly et al. [48] & $95 / 65$ & NA & $65 / 95$ & $60 / 100$ & $88(55 \%)$ & Greater than $0.2 \mathrm{ng} / \mathrm{ml}$ \\
\hline Busch et al. [49] & 1538/307 & NA & $1802 / 9$ & $537 / 1308$ & $450(24.4 \%)$ & $P S A \geqq 0.1 \mathrm{ng} / \mathrm{ml}$ with confirmatory rise \\
\hline Berge et al. [50] & $553 / 24$ & TNM 2002 & $441 / 136$ & $168 / 409$ & $91(16 \%)$ & Two consecutive increases in PSA $\geqq 0.2 \mathrm{ng} / \mathrm{ml}$ \\
\hline Lee et al. [51] & 236/764 & NA & NA & $337 / 663$ & $99(9.9 \%)$ & Two consecutive increases in PSA $\geqq 0.2 \mathrm{ng} / \mathrm{ml}$ \\
\hline Alenda et al. [23] & $1248 / 0$ & NA & NA & $400 / 843$ & $176(16.9 \%)$ & $P S A>0.2 \mathrm{ng} / \mathrm{mL}$ \\
\hline Fukuhara et al. [52] & $332 / 32$ & TNM 2002 & $275 / 89$ & $157 / 207$ & $66(18.1 \%)$ & Two consecutive increases in PSA $\geqq 0.2 \mathrm{ng} / \mathrm{ml}$ \\
\hline Cho et al. [53] & $153 / 14$ & TNM 2002 & $126 / 45$ & $58 / 109$ & $15(8.8 \%)$ & A serum PSA value of $0.4 \mathrm{ng} / \mathrm{ml}$ or greater after RP \\
\hline Alkhateeb et al. [26] & $1159 / 109$ & NA & $853 / 415$ & $264 / 1004$ & NA & A serum PSA value of $0.4 \mathrm{ng} / \mathrm{ml}$ or greater after RP \\
\hline Jeon et al. [54] & $190 / 45$ & TNM 2002 & $145 / 92$ & $86 / 151$ & $67(28.3 \%)$ & Two consecutive increases in PSA $\geqq 0.2 \mathrm{ng} / \mathrm{ml}$ \\
\hline Schroeck et al. [55] & $2855 / 359$ & NA & 1991/1166 & $982 / 2212$ & $706(25.7 \%)$ & Greater than $0.2 \mathrm{ng} / \mathrm{ml}$ \\
\hline Pavlovich et al. [56] & $494 / 14$ & TNM 2002 & $416 / 92$ & $69 / 439$ & $102(20 \%)$ & Two consecutive increases in PSA $\geqq 0.2 \mathrm{ng} / \mathrm{ml}$ \\
\hline Hong et al. [57] & $361 / 11$ & TNM 2002 & $371 / 0$ & $46 / 326$ & NA & First value greater than $0.2 \mathrm{ng} / \mathrm{ml}$ \\
\hline Cheng et al. [8] & $410 / 94$ & TNM 1997 & $348 / 156$ & $174 / 330$ & $157(21.2 \%)$ & Two consecutive increases in PSA $\geqq 0.1 \mathrm{ng} / \mathrm{ml}$ \\
\hline Shariat et al. [58] & $565 / 65$ & TNM 1997 & NA & $179 / 451$ & $80(12.7 \%)$ & First value greater than $0.2 \mathrm{ng} / \mathrm{ml}$ \\
\hline
\end{tabular}


defined; (4) the risk of BCR was estimated as hazard ratios (HRs) with corresponding 95\% confidence intervals (CIs) or the risk could be calculated from the reported data; and (5) published in English or Chinese. The following exclusion criteria were used: (1) letters, reviews, case reports, editorials, and author responses; (2) non-human studies; (3) studies that did not analyse the outcome after PSM and BCR; (4) studies with duplicated patient populations that had been reported in previous publications; or (5) articles contained elements that were inconsistent with the inclusion criteria.

\section{Data extraction and quality assessment}

Two investigators (Zhenlei Zha and Hu Zhao) independently extracted the data from all eligible publications. Any differences among evaluators were resolved by discussion with a third investigator (BinWu). The following data were extracted from the included studies using a standardised data collection protocol (Table 1, Table 2): first author's name, year of publication, country, recruitment period, sample size, patient's age, preoperative PSA level, Gleason score, pathological stage, positive percentage of PSM and
BCR, definition of BCR, follow-up time, and the HRs (95\% CIs) of PSM in univariate or multivariate Cox analyses for BCR. The quality of the eligible studies was evaluated according to the Newcastle-Ottawa Scale (NOS), which include three domains (selection of the study population, comparability of the groups, ascertainment of the outcome). We identified articles of "high quality" as those with NOS scores of 6-9, whereas scores of $0-5$ were considered to indicate poor quality.

\section{Statistical analyses}

All statistical analyses in this meta-analysis were performed by Stata 12.0 software (Stat Corp, College Station, TX, USA). The association between PSM and BCR outcome was presented as summary relative risk estimates (SRREs) and 95\% CIs. Heterogeneity between studies was calculated by the chi-square-based $Q$ test and $I^{2}$. A value of $p<0.10$ or $I^{2}>50 \%$ was considered as statistically significant heterogeneity. A random-effects model was used if heterogeneity was significant, and otherwise, a fixed-effects model was used. Sensitivity analysis was used to estimate the reliability of the pooled

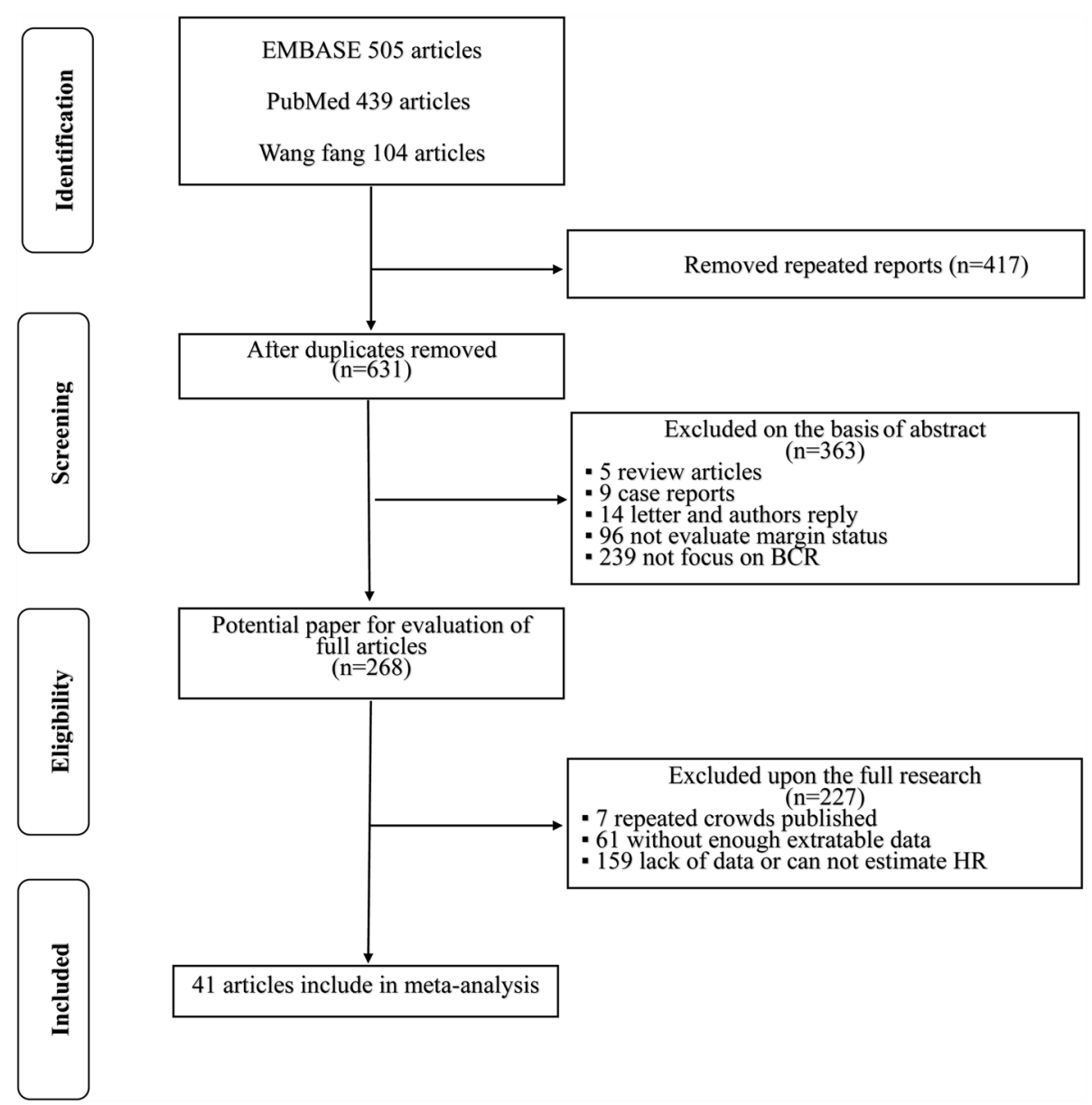

Fig. 1 Flow diagram of the study selection process for this meta-analysis 
results via the sequential omission of each study. Subgroup analysis was performed to check whether the pooled HR was influenced by the region, publication year, mean age, sample size, mean preoperative PSA (p-PSA), median follow-up, and the cut-off value for BCR. To assess the stability of the combined HR, sensitivity analysis was performed by removing individual studies from the meta-analysis. Publication bias was assessed by funnel plots and was statistically determined by Egger's linear regression. Statistical significance was defined as a two-tailed value of $p<0.05$, except for the heterogeneity tests.

\section{Results}

\section{Literature search and study characteristics}

The full process of the systematic literature review is shown in Fig. 1. In accordance with the PRISMA search strategy, 1048 relevant studies were initially identified. After carefully reading each article, 780 studies were excluded for the following reasons: duplicates, letters, or reviews; or contained no evaluated margin status and focus on BCR. After the remaining studies $(n=268)$ were reviewed, additional studies were excluded because certain cohorts were studied more than once or relevant data were lacking. Forty-one high-quality retrospective studies comprising 37,928 patients (94-3294 per study) were ultimately included in the meta-analysis.

The primary characteristics of the included studies are summarised in Table 1. All studies were published between 2004 and 2017. Of these, 19 studies were conducted in an Asian country, and 12 were conducted in North America; the rest were conducted in Europe (7) or in multiple countries (3). The median follow-up period of the studies ranged from 14 to 174 months. All included studies were published in English, except for two that were in Chinese. Of all of the studies, 8 used laparoscopic RP, 7 used robot-assisted RP, and 3 used open RP. BCR was defined using different cut-off values $(0.1 \mathrm{ng} / \mathrm{ml}, 0.2 \mathrm{ng} / \mathrm{ml}, 0.4 \mathrm{ng} / \mathrm{ml})$ among the included studies, and the incidence of BCR after RP ranged from 8.8 to $66.5 \%$ according to the reported values (Table 2). NOS [17] was applied to assess the quality of the included studies, and the results showed that all of the studies were of high quality with an NOS score $\geq 7$. (Additional file 1: Table S1).

\section{Meta-analysis}

The forest plots of the meta-analysis in our study demonstrated that PSM was associated with poorer BCR in RP patients by univariate analysis (random-effects model, pooled $\mathrm{HR}=1.56$; 95\% CI 1.46, 1.66; $p<0.001$; Fig. 2) and

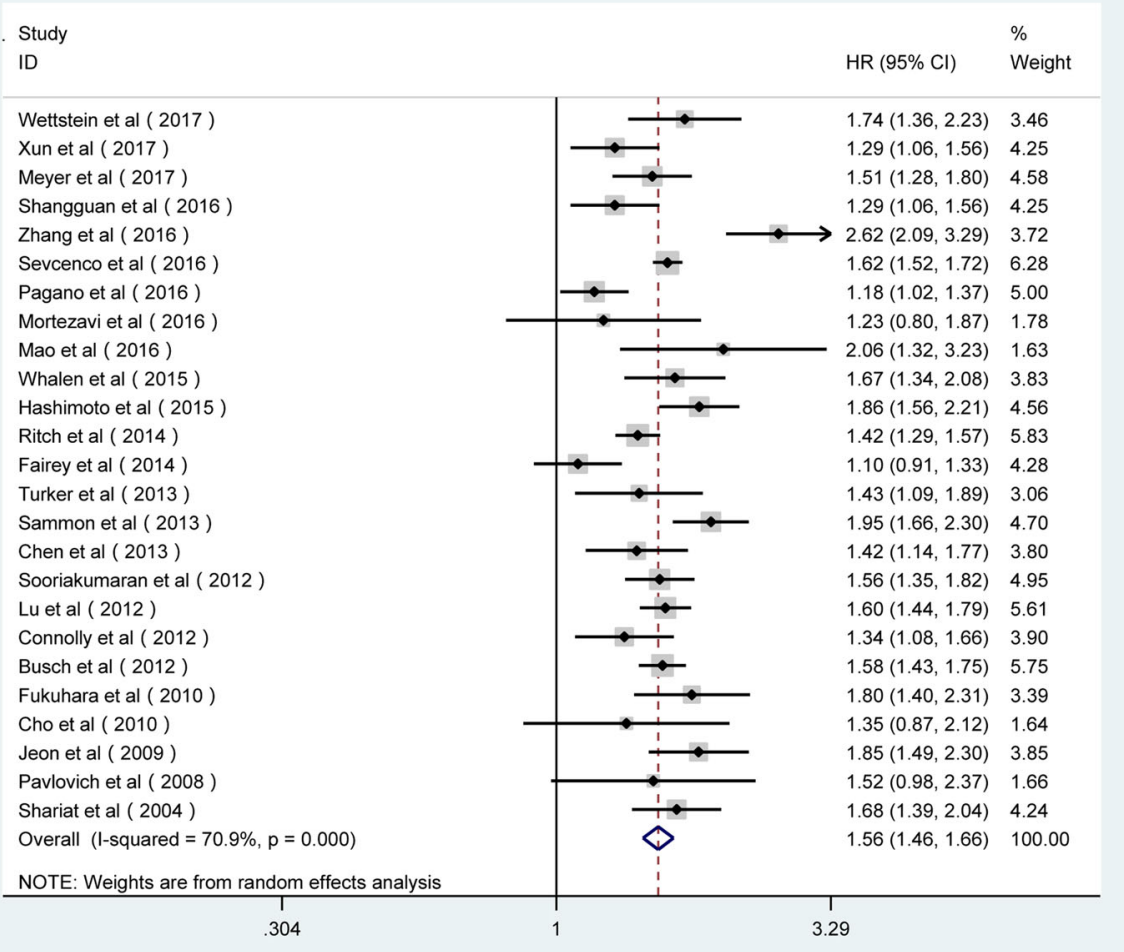

Fig. 2 Forest plots of the association between PSM and BCR risk in the stratification analysis by univariate mode 
multivariate analysis (random-effects model, pooled $\mathrm{HR}=$ 1.35; 95\% CI 1.27, 1.43; $p<0.001$; Fig. 3). Given the large heterogeneity between the studies, subgroup analyses were performed by region, publication year, mean age, sample size, mean preoperative PSA (p-PSA), median follow-up, and the cut-off value for BCR. Although no significant modifiers accounting for the inter-study heterogeneity were detected, the results of subgroup analyses were consistent with the primary findings (Table 3).

\section{The sensitivity analysis and publication bias}

With a sensitivity analysis, the overall significance did not change when any single study was omitted. The summary relative risk estimate (SRRE) for BCR ranged from 1.52 (95\% CI, 1.44-1.62) to 1.58 (95\% CI, 148-1.68) (Fig. 4a) in univariate analysis and $1.34(95 \% \mathrm{CI}, 1.26-1.42)$ to 1.37 (95\% CI, 1.29-1.45) (Fig. 4b) in multivariate analysis. These results indicated that the findings were reliable and robust. To test for publication bias, Egger's linear regression was performed. No significant publication bias was detected between these studies regarding $\mathrm{HR}$ of BCR in univariate analysis (p-Begg $=0.971$; Fig. 5a) and multivariate analysis ( $\mathrm{p}$-Begg $=0.401$; Fig. 5b), respectively.

\section{Discussion}

With the increased public awareness and wide use of PSA-based screening, the number of patients diagnosed with PCa annually has been increasing [6]. Because RP provides superior cancer control and functional outcomes, this surgery has become a standard first-line treatment for eligible patients [18]. However, despite various advances in surgical technology, $\mathrm{BCR}$ has been reported in approximately $25-35 \%$ patients after RP and even more patients with intermediate-high risk [19]. Because BCR reportedly leads to distant metastasis and cancer death [20], it is necessary for men with BCR to undergo salvage radiation or hormonal therapy [11]. Therefore, identifying modifiable factors that affect the progression of BCR may help physicians in the selection of patients who are more likely to benefit from adjuvant multimodal therapy.

A number of nomograms have been developed to predict BCR after RP using either preoperative or postoperative variables [21]. Several clinical and pathologic factors have been included in these models, most of which cannot be altered by the treating physician (preoperative PSA [22], pathological T stage [5], pathological

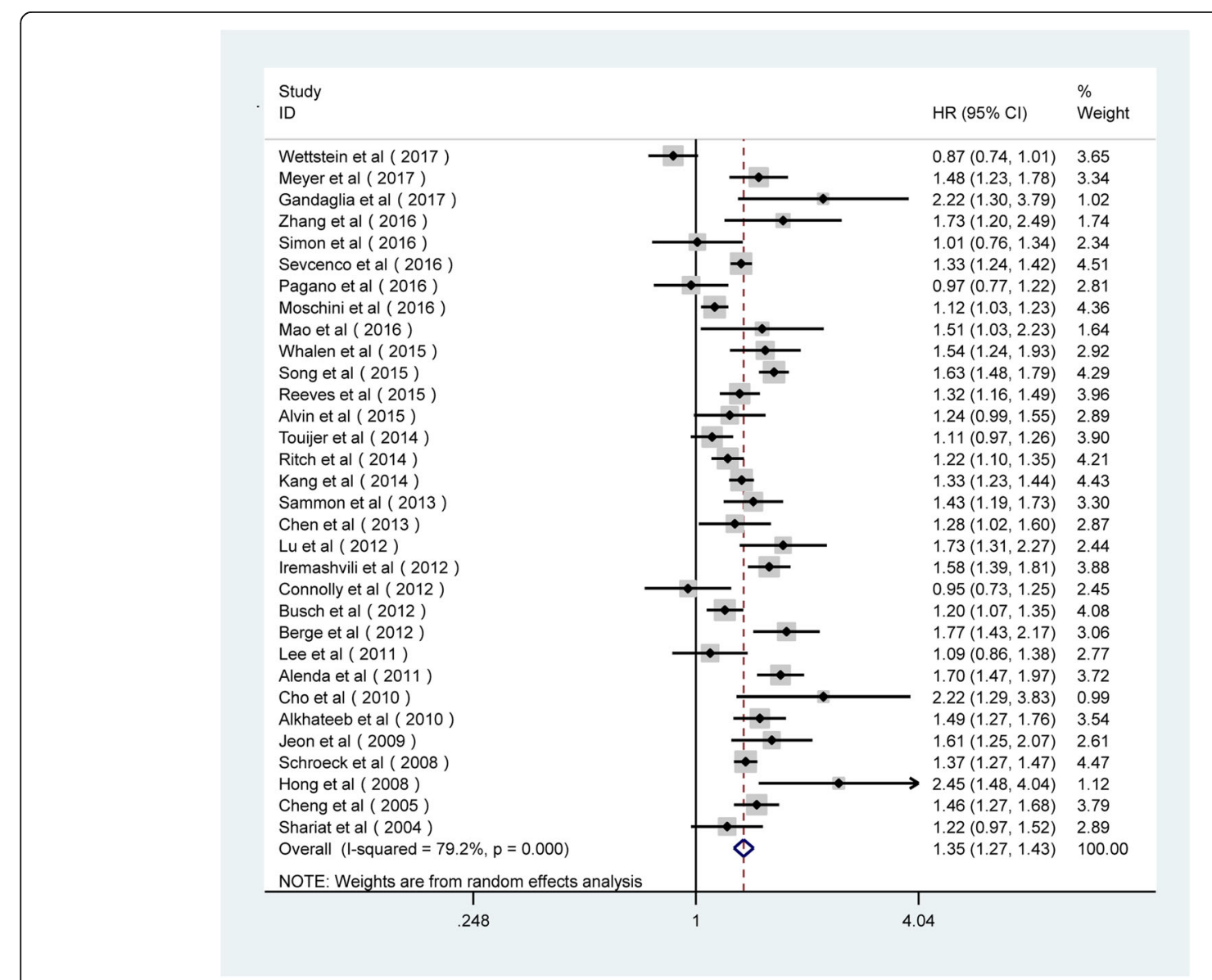

Fig. 3 Forest plots of the association between PSM and BCR risk in the stratification analysis by multivariate mode 
Table 3 Overall analyses and subgroup analyses for the included studies

\begin{tabular}{|c|c|c|c|c|c|c|}
\hline \multirow[t]{2}{*}{ Analysis specification } & \multirow[t]{2}{*}{ No. of studies } & \multicolumn{2}{|c|}{ Study heterogeneity } & \multirow[t]{2}{*}{ Effects model } & \multirow[t]{2}{*}{ Pooled HR (95\% CI) } & \multirow[t]{2}{*}{$p$ value } \\
\hline & & $\bar{P}(\%)$ & $\overline{p_{\text {heterogeneity }}}$ & & & \\
\hline \multicolumn{7}{|l|}{ Univariate analysis (BCR) } \\
\hline Overall & 25 & 70.9 & $<0.001$ & Random & $1.56(1.46,1.66)$ & $<0.001$ \\
\hline \multicolumn{7}{|l|}{ Geographical region } \\
\hline Asia & 12 & 72.1 & $<0.001$ & Random & $1.61(1.43,182)$ & $<0.001$ \\
\hline Europe and North America & 12 & 70.8 & $<0.001$ & Random & $1.50(1.37,1.65)$ & $<0.001$ \\
\hline \multicolumn{7}{|l|}{ Date of publication } \\
\hline$\geq 2014$ & 13 & 81.8 & $<0.001$ & Random & $1.52(1.36,1.70)$ & $<0.001$ \\
\hline$<2014$ & 12 & 18.5 & 0.262 & Fixed & $1.61(1.52,1.71)$ & $<0.001$ \\
\hline \multicolumn{7}{|l|}{ Mean age (years) } \\
\hline$\geq 64$ & 9 & 84 & $<0.001$ & Random & $1.62(1.34,1.97)$ & $<0.001$ \\
\hline$<64$ & 15 & 55.6 & 0.005 & Random & $1.54(1.45,1.64)$ & $<0.001$ \\
\hline \multicolumn{7}{|l|}{ Sample size (cases) } \\
\hline$\geq 500$ & 10 & 40.1 & 0.09 & Random & $1.61(1.52,1.70)$ & $<0.001$ \\
\hline$<500$ & 15 & 76.9 & $<0.001$ & Random & $1.51(1.33,1.71)$ & $<0.001$ \\
\hline \multicolumn{7}{|l|}{ Mean p-PSA (ng/ml) } \\
\hline$\geq 10$ & 7 & 81 & $<0.001$ & Random & $1.65(1.38,1.97)$ & $<0.001$ \\
\hline$<10$ & 14 & 58.5 & 0.003 & Random & $1.59(1.48,1.71)$ & $<0.001$ \\
\hline \multicolumn{7}{|l|}{ Median follow-up } \\
\hline$\geq 36$ months & 11 & 77.1 & $<0.001$ & Random & $1.49(1.33,1.67)$ & $<0.001$ \\
\hline$<36$ months & 14 & 59.8 & 0.002 & Random & $1.61(1.49,1.74)$ & $<0.001$ \\
\hline \multicolumn{7}{|l|}{$\mathrm{BCR}(\mathrm{ng} / \mathrm{ml})$} \\
\hline Cutoff value 0.1 & 4 & 0 & 0.775 & Fixed & $1.61(1.49,1.72)$ & $<0.001$ \\
\hline Cutoff value 0.2 & 20 & 72 & $<0.001$ & Random & $1.58(1.46,1.70)$ & $<0.001$ \\
\hline Cutoff value 0.4 & 1 & - & - & - & - & - \\
\hline \multicolumn{7}{|l|}{ Multivariate analysis (BCR) } \\
\hline Overall & 32 & 79.2 & $<0.001$ & Random & $1.35(1.27,1.43)$ & $<0.001$ \\
\hline \multicolumn{7}{|l|}{ Geographical region } \\
\hline Asia & 14 & 67 & $<0.001$ & Random & $1.42(1.29,1.55)$ & $<0.001$ \\
\hline Europe and North America & 15 & 84.7 & $<0.001$ & Random & $1.31(1.19,1.43)$ & $<0.001$ \\
\hline Multi-centred & 3 & 71.9 & 0.029 & Random & $1.33(1.00,1.78)$ & 0.053 \\
\hline \multicolumn{7}{|l|}{ Date of publication } \\
\hline$\geq 2014$ & 16 & 82.9 & $<0.001$ & Random & $1.27(1.17,1.39)$ & $<0.001$ \\
\hline$<2014$ & 16 & 67.2 & $<0.001$ & Random & $1.44(1.32,1.56)$ & $<0.001$ \\
\hline \multicolumn{7}{|l|}{ Mean age (years) } \\
\hline$\geq 64$ & 8 & 62.5 & 0.009 & Random & $1.56(1.32,1.85)$ & $<0.001$ \\
\hline$<64$ & 22 & 81.5 & $<0.001$ & Random & $1.33(1.24,1.43)$ & $<0.001$ \\
\hline \multicolumn{7}{|l|}{ Sample size (cases) } \\
\hline$\geq 500$ & 18 & 77.1 & $<0.001$ & Random & $1.40(1.32,1.49)$ & $<0.001$ \\
\hline$<500$ & 14 & 76.8 & $<0.001$ & Random & $1.28(1.12,1.47)$ & $<0.001$ \\
\hline \multicolumn{7}{|l|}{ Mean p-PSA (ng/ml) } \\
\hline$\geq 10$ & 7 & 80.8 & $<0.001$ & Random & $1.36(1.22,1.57)$ & $<0.001$ \\
\hline$<10$ & 19 & 79 & $<0.001$ & Random & $1.35(1.24,1.48)$ & $<0.001$ \\
\hline
\end{tabular}

Median follow-up 
Table 3 Overall analyses and subgroup analyses for the included studies (Continued)

\begin{tabular}{|c|c|c|c|c|c|c|}
\hline \multirow[t]{2}{*}{ Analysis specification } & \multirow[t]{2}{*}{ No. of studies } & \multicolumn{2}{|c|}{ Study heterogeneity } & \multirow[t]{2}{*}{ Effects model } & \multirow[t]{2}{*}{ Pooled HR (95\% Cl) } & \multirow[t]{2}{*}{$p$ value } \\
\hline & & $\bar{P}(\%)$ & $\overline{p_{\text {heterogeneity }}}$ & & & \\
\hline$\geq 36$ months & 16 & 79.6 & $<0.001$ & Random & $1.36(1.24,1.46)$ & $<0.001$ \\
\hline$<36$ months & 15 & 79.8 & $<0.001$ & Random & $1.34(1.21,1.47)$ & $<0.001$ \\
\hline \multicolumn{7}{|l|}{$\mathrm{BCR}(\mathrm{ng} / \mathrm{ml})$} \\
\hline Cutoff value 0.1 & 5 & 87.7 & $<0.001$ & Random & $1.22(1.01,1.48)$ & 0.044 \\
\hline Cutoff value 0.2 & 23 & 71.3 & $<0.001$ & Random & $1.39(1.30,1.48)$ & $<0.001$ \\
\hline Cutoff value 0.4 & 4 & 82.2 & 0.001 & Random & $1.34(1.15,1.57)$ & $<0.001$ \\
\hline
\end{tabular}

Gleason score [23]). The D'Amico risk stratification scheme [20] and Cancer of the Prostate Risk Assessment (CAPRA) score [24] have also been adopted in the urological community to predict the probability of BCR. Although these nomograms have been internationally validated, unfortunately, only a small number of them have predicted the probability of 5-year BCR with more than $70 \%$ accuracy [25]. Thus, efforts to improve existing outcome prediction tools for $\mathrm{PCa}$ are always encouraged.

PSM is a frequent situation encountered after radical prostatectomy (RP) for localised PCa with an occurrence ranging from 6 to $41 \%[9,26,27]$. The incidence of PSM depends on various factors, including tumour biology, patient characteristics, pathological assessment method, and surgical technique [28]. We reported an overall PSM rate of $45.7 \%(17,339 / 37,928)$, which was slightly higher than other large series. Because the goal of surgical procedures is the complete removal of the tumour, the presence of PSM after RP is considered to be an adverse outcome associated with failure of the surgery to cure the PCa. However, the effects of PSM on clinical outcomes and the risk of BCR are still unclear. Several studies concluded that a PSM is an independent factor of BCR in patients with PCa after RP [11, 29-31]. However, not all patients with PSM show recurrence according to other studies [27, 28, 32]. Moreover, several reports showed that the effect of PSMs on prognosis depends on certain clinical and pathological features of the disease [26].

To the best of our knowledge, this study is the most up-to-date and informative meta-analysis on the association between PSM and BCR risk. The results obtained in our meta-analysis are in line with the previous systematic review by Yossepowitch et al. In addition, our study presented a series of advancements in comparison with previous studies. First, we included more eligible studies with high quality. The search by Yossepowitch et al. included studies up to 2013. However, our search included 21 additional studies published from 2014 to 2017, thereby improving the evaluation on the effect and enabling more subgroup analyses. In addition, the studies retrieved for our analysis were not limited to English; two Chinese articles $[33,34]$ also met the criteria for inclusion.

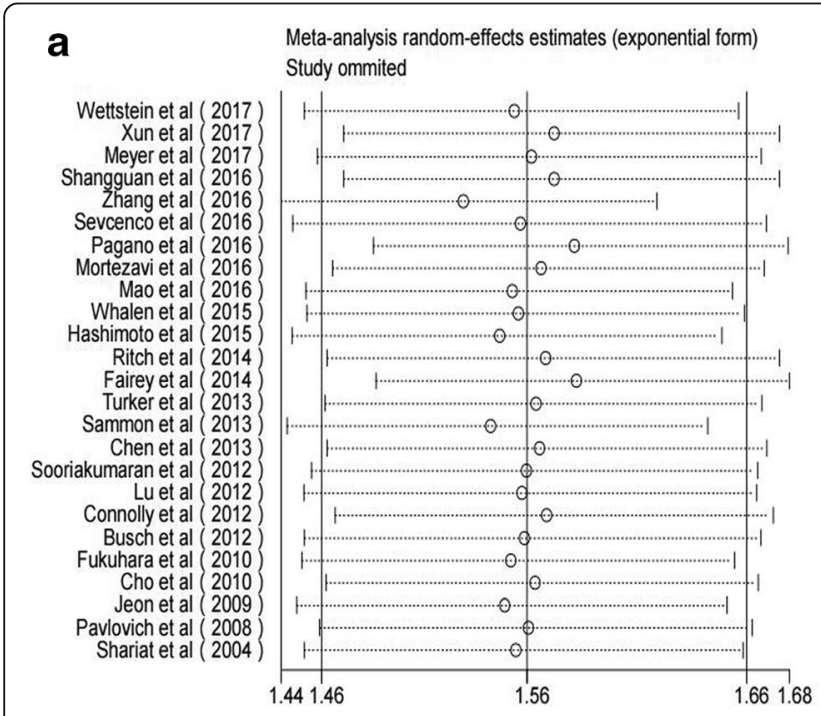

b

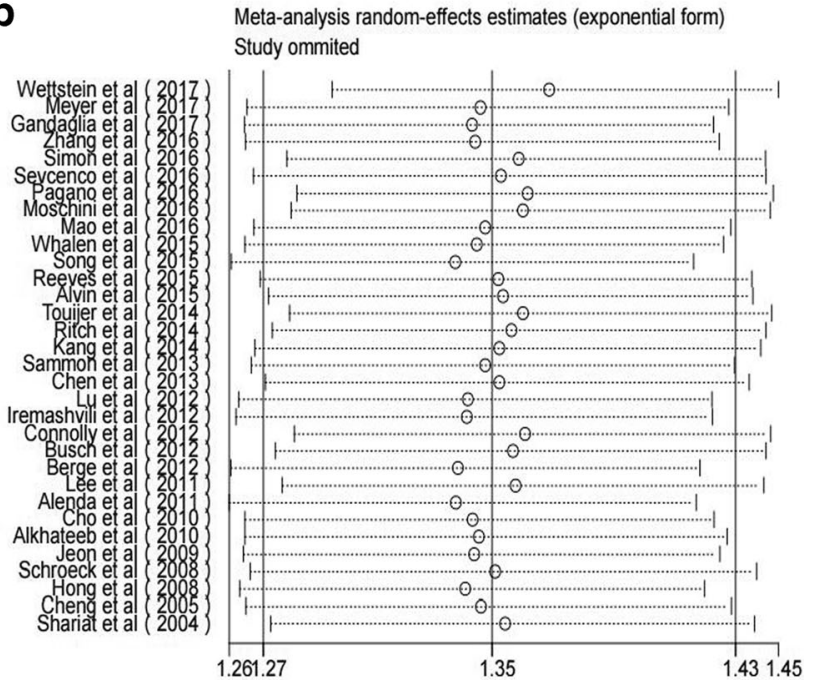

Fig. 4 Sensitivity analysis of the association between PSM and BCR risk in PCa patients. a Univariate analysis mode. b Multivariate analysis mode 

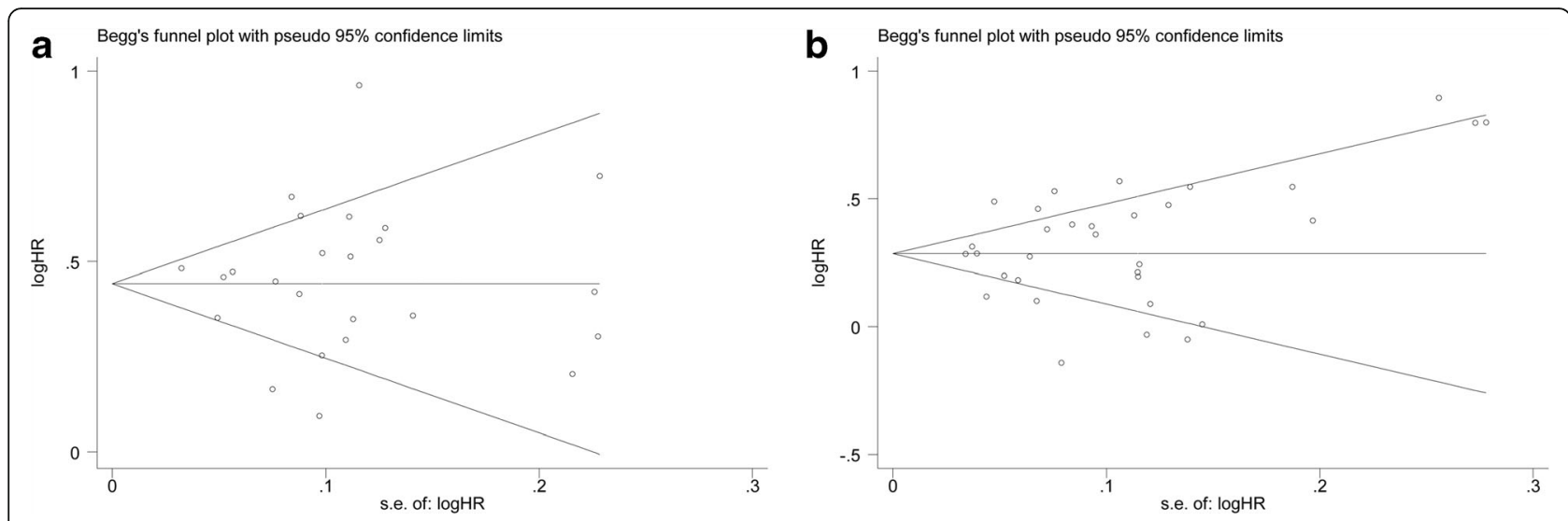

Fig. 5 Funnel plots and Begg's tests for the evaluation of potential publication bias. a Univariate analysis mode. b Multivariate analysis mode

Similar to Yossepowitch et al., we identified a significant relationship between PSM and BCR in RP. However, we also found that the pooled result of PSM had a large heterogeneity in both univariate $\left(I^{2}=70.9 \%\right)$ and multivariate $\left(I^{2}=79.2 \%\right)$ analyses. Even though the cut-offs varied among the included studies $(0.1 \mathrm{ng} / \mathrm{ml}$, $0.2 \mathrm{ng} / \mathrm{ml}, 0.4 \mathrm{ng} / \mathrm{ml}$ ), the subgroup analyses achieved results similar to both univariate and multivariate analyses (Table 3). Meanwhile, the sensitivity analysis of our study revealed that the omission of each study did not have a significant impact on the merged value of HR.

However, several limitations of this study should be considered. First and foremost, all included studies were retrospective; therefore, the data extracted from those studies may have led to potential inherent bias. Second, the criteria to determine the presence of PSM in the pathological specimen were inconsistent in the included studies, which may have potentially contributed to heterogeneity. Thus, rigorous morphological criteria should be established to standardise the diagnosis of PSM. Third, substantial heterogeneity was observed in the meta-analysis, and although we used the random-effects model according to heterogeneity, it still existed in our studies. Moreover, from the subgroup analyses, we believed that the heterogeneity was caused by differences in factors such as patient and tumour characteristics. Finally, studies with negative results tend to be unsubmitted or unpublished; grey literature was not included, meaning that language bias may have been present in this study.

\section{Conclusions}

In conclusion, this meta-analysis demonstrates that PSM has a detrimental effect on BCR risk in patients with PCa after RP and could therefore be considered to be an independent prognostic factor of BCR. Due to PSM's excellent feasibility and low cost, this method should be more widely employed for BCR risk stratification and BCR prediction in patients with $\mathrm{PCa}$. Given the inherent limitations of retrospective studies, further research is warranted, preferably with a longer follow-up period, to elucidate the potential role of PSM in influencing BCR risk.

\section{Additional file}

Additional file 1: Table S1. Quality assessment of cohort studies included in this meta-analysis. (DOCX $20 \mathrm{~kb}$ )

Availability of data and materials

All data generated or analysed during this study are included in this published article (and its supplementary information files).

\section{Authors' contributions}

LZ and BW contributed to the conceptualization. ZZ, HZ, and BW contributed to the literature search. $Y J$ and $Y J$ contributed to the data analysis. ZZ, HZ, and $Y J$ contributed to the writing of the original draft. $L Z$ contributed to the writing and review and editing. All authors read and approved the final manuscript

Ethics approval and consent to participate Not applicable.

\section{Consent for publication}

I give my consent for information about my relative circle to be published in the World Journal of Surgical Oncology (WJSO-D-18-00097R1, Lijin Zhang). I understand that the information will be published without my relative's (circle as appropriate) name attached, but that full anonymity cannot be guaranteed. I understand that the text and any pictures or videos published in the article will be freely available on the internet and may be seen by the general public. The pictures, videos, and text may also appear on other websites or in print, may be translated into other languages, or used for commercial purposes. I have been offered the opportunity to read the manuscript.

Competing interests

The authors declare that they have no competing interests.

\section{Publisher's Note}

Springer Nature remains neutral with regard to jurisdictional claims in published maps and institutional affiliations. 
Received: 30 January 2018 Accepted: 26 June 2018 Published online: 03 July 2018

\section{References}

1. Siegel RL, Miller KD, Jemal A. Cancer statistics, 2016. CA Cancer J Clin. 2016;66:7-30.

2. Fujimura $T$, Fukuhara $H$, Taguchi $S$, Yamada $Y$, Sugihara $T$, Nakagawa T, Niimi A, Kume H, Igawa $Y$, Homma Y. Robot-assisted radical prostatectomy significantly reduced biochemical recurrence compared to retro pubic radical prostatectomy. BMC Cancer. 2017;17:454.

3. Isbarn H, Wanner M, Salomon G, Steuber T, Schlomm T, Kollermann J, Sauter G, Haese A, Heinzer H, Huland H, Graefen M. Long-term data on the survival of patients with prostate cancer treated with radical prostatectomy in the prostate-specific antigen era. BJU Int. 2010;106:37-43.

4. Thompson IM, Valicenti RK, Albertsen P, Davis BJ, Goldenberg SL, Hahn C, Klein E, Michalski J, Roach M, Sartor O, et al. Adjuvant and salvage radiotherapy after prostatectomy: AUA/ASTRO guideline. J Urol. 2013;190:441-9.

5. Hashimoto T, Yoshioka K, Horiguchi Y, Inoue R, Yoshio O, Nakashima J, Tachibana M. Clinical effect of a positive surgical margin without extraprostatic extension after robot-assisted radical prostatectomy. Urol Oncol. 2015;33:503.e501-6.

6. Shangguan X, Dong B, Wang Y, Xu F, Shao X, Sha J, Zhu Y, Pan J, Xue W. Management of prostate cancer patients with locally adverse pathologic features after radical prostatectomy: feasibility of active surveillance for cases with Gleason grade 3 + 4= 7. J Cancer Res Clin Oncol. 2017;143:123-9.

7. Moschini M, Sharma V, Gandaglia G, Dell'Oglio P, Fossati N, Zaffuto E. Longterm utility of adjuvant hormonal and radiation therapy for patients with seminal vesicle invasion at radical prostatectomy. BJU Int. 2017;120:69-75.

8. Cheng L, Jones TD, Lin H, Eble JN, Zeng G, Carr MD, Koch MO. Lymphovascular invasion is an independent prognostic factor in prostatic adenocarcinoma. J Urol. 2005;174:2181-5.

9. Hsu M, Chang SL, Ferrari M, Nolley R, Presti JC Jr, Brooks JD. Length of sitespecific positive surgical margins as a risk factor for biochemical recurrence following radical prostatectomy. Int J Urol. 2011;18:272-9.

10. Sammon JD, Trinh QD, Sukumar S, Ravi P, Friedman A, Sun M, Schmitges J, Jeldres C, Jeong W, Mander N, et al. Risk factors for biochemical recurrence following radical perineal prostatectomy in a large contemporary series: a detailed assessment of margin extent and location. Urol Oncol. 2013;31:1470-6.

11. Sooriakumaran $P$, Haendler L, Nyberg T, Gronberg H, Nilsson A, Carlsson S, Hosseini A, Adding C, Jonsson M, Ploumidis A, et al. Biochemical recurrence after robot-assisted radical prostatectomy in a European single-centre cohort with a minimum follow-up time of 5 years. Eur Urol. 2012;62:768-74.

12. Simon RM, Howard LE, Freedland SJ, Aronson WJ, Terris MK, Kane CJ, Amling CL, Cooperberg MR, Vidal AC. Adverse pathology and undetectable ultrasensitive prostate-specific antigen after radical prostatectomy: is adjuvant radiation warranted? BJU Int. 2016;117:897-903.

13. Touijer KA, Mazzola CR, Sjoberg DD, Scardino PT, Eastham JA. Long-term outcomes of patients with lymph node metastasis treated with radical prostatectomy without adjuvant androgen-deprivation therapy. Eur Urol. 2014;65:20-5.

14. Fairey AS, Daneshmand S, Skinner EC, Schuckman A, Cai J, Lieskovsky G. Long-term cancer control after radical prostatectomy and bilateral pelvic lymph node dissection for pT3bNOMO prostate cancer in the prostatespecific antigen era. Urol Oncol. 2014;32:85-91.

15. Yossepowitch O, Briganti A, Eastham JA, Epstein J, Graefen M, Montironi R, Touijer K. Positive surgical margins after radical prostatectomy: a systematic review and contemporary update. Eur Urol. 2014;65:303-13.

16. Pashaei E, Pashaei E, Ahmady M, Ozen M, Aydin N. Meta-analysis of miRNA expression profiles for prostate cancer recurrence following radical prostatectomy. PLoS One. 2017;12:e0179543.

17. Stang A. Critical evaluation of the Newcastle-Ottawa scale for the assessment of the quality of nonrandomized studies in meta-analyses. Eur J Epidemiol. 2010;25:603-5

18. Miocinovic R, Berglund RK, Stephenson AJ, Jones JS, Fergany A, Kaouk J, Klein EA. Avoiding androgen deprivation therapy in men with high-risk prostate cancer: the role of radical prostatectomy as initial treatment. Urology. 2011;77:946-50.

19. Kumar A, Samavedi S, Mouraviev V, Bates AS, Coelho RF, Rocco B, Patel VR. Predictive factors and oncological outcomes of persistently elevated prostate-specific antigen in patients following robot-assisted radical prostatectomy. J Robot Surg. 2017;11:37-45.

20. Pagano MJ, Whalen MJ, Paulucci DJ, Reddy BN, Matulay JT, Rothberg M, Scarberry K, Patel T, Shapiro EY, RoyChoudhury A, et al. Predictors of biochemical recurrence in $\mathrm{pT} 3 \mathrm{~b}$ prostate cancer after radical prostatectomy without adjuvant radiotherapy. Prostate. 2016;76:226-34.

21. Kang M, Jeong CW, Choi WS, Park YH, Cho SY, Lee S, Lee SB, Ku JH, Hong SK, Byun SS, et al. Pre- and post-operative nomograms to predict recurrence-free probability in Korean men with clinically localized prostate cancer. PLoS One. 2014;9:e100053.

22. Ku JH, Moon KC, Cho SY, Kwak C, Kim HH. Serum prostate-specific antigen value adjusted for non-cancerous prostate tissue volume in patients undergoing radical prostatectomy: a new predictor of biochemical recurrence in localized or locally advanced prostate cancer. Asian J Androl. 2011;13:248-53.

23. Alenda O, Ploussard G, Mouracade P, Xylinas E, de la Taille A, Allory Y, Vordos D, Hoznek A, Abbou CC, Salomon L. Impact of the primary Gleason pattern on biochemical recurrence-free survival after radical prostatectomy: a single-center cohort of 1,248 patients with Gleason 7 tumors. World J Urol. 2011;29:671-6.

24. Cooperberg MR, Pasta DJ, Elkin EP, Litwin MS, Latini DM, Du Chane J, Carroll PR. The University of California, San Francisco Cancer of the Prostate Risk Assessment score: a straightforward and reliable preoperative predictor of disease recurrence after radical prostatectomy. J Urol. 2005;173:1938-42.

25. Zhang YD, Wang J, Wu CJ, Bao ML, Li H, Wang XN, Tao J, Shi HB. An imaging-based approach predicts clinical outcomes in prostate cancer through a novel support vector machine classification. Oncotarget. 2016;7: 78140-51.

26. Alkhateeb S, Alibhai S, Fleshner N, Finelli A, Jewett M, Zlotta A, Nesbitt M, Lockwood G, Trachtenberg J. Impact of positive surgical margins after radical prostatectomy differs by disease risk group. J Urol. 2010;183:145-50.

27. Pettenati C, Neuzillet Y, Radulescu C, Herve JM, Molinie V, Lebret T. Positive surgical margins after radical prostatectomy: what should we care about? World J Urol. 2015:33:1973-8.

28. Stephenson AJ, Wood DP, Kattan MW, Klein EA, Scardino PT, Eastham JA, Carver BS. Location, extent and number of positive surgical margins do not improve accuracy of predicting prostate cancer recurrence after radical prostatectomy. J Urol. 2009;182:1357-63.

29. Whalen MJ, Shapiro EY, Rothberg MB, Turk AT, Woldu SL, Roy Choudhury A, Patel T, Badani KK. Close surgical margins after radical prostatectomy mimic biochemical recurrence rates of positive margins. Urol Oncol. 2015;33:494.e499-14.

30. Chen MK, Luo Y, Zhang H, Qiu JG, Wen XQ, Pang J, Si-Tu J, Sun QP, Gao X. Laparoscopic radical prostatectomy plus extended lymph nodes dissection for cases with non-extra node metastatic prostate cancer: 5-year experience in a single Chinese institution. J Cancer Res Clin Oncol. 2013;139:871-8.

31. Lu J, Wirth GJ, Wu S, Chen J, Dahl DM, Olumi AF, Young RH, McDougal WS, Wu CL. A close surgical margin after radical prostatectomy is an independent predictor of recurrence. J Urol. 2012;188:91-7.

32. Simon MA, Kim S, Soloway MS. Prostate specific antigen recurrence rates are low after radical retropubic prostatectomy and positive margins. J Urol. 2006;175:140-4. discussion 144-145

33. Shangguan X, Dong B, Pan J, Xu F, Wang Y, Shao X, Huang Y, Xue W. Establishment and evaluation of nomogram for predicting biochemical recurrence in patients with locally adverse pathologic features after radical prostatectomy. Chinese J Urology. 2016;37:827-32

34. Zhang S, Jiang W, Yuan Y, Zhang L, Ji C, Guo H. Prognostic significance of modified Gleason scoring system after radical prostatectomy. Chinese J Urology. 2016;37:344-8.

35. Wettstein MS, Saba K, Umbehr MH, Murtola TJ, Fankhauser CD, Adank JP, Hofmann M, Sulser T, Hermanns T, Moch H, et al. Prognostic role of preoperative serum lipid levels in patients undergoing radical prostatectomy for clinically localized prostate cancer. Prostate. 2017;77:549-56.

36. Meyer CP, Hansen J, Boehm K, Tilki D, Abdollah F, Trinh QD, Fisch M, Sauter $\mathrm{G}$, Graefen $\mathrm{M}$, Huland $\mathrm{H}$, et al. Tumor volume improves the long-term prediction of biochemical recurrence-free survival after radical prostatectomy for localized prostate cancer with positive surgical margins. World J Urol. 2017;35:199-206.

37. Gandaglia G, De Lorenzis E, Novara G, Fossati N, De Groote R, Dovey Z, Suardi N, Montorsi F, Briganti A, Rocco B, Mottrie A. Robot-assisted radical prostatectomy and extended pelvic lymph node dissection in patients with locally-advanced prostate cancer. Eur Urol. 2017;71:249-56. 
38. Sevcenco S, Mathieu R, Baltzer P, Klatte T, Fajkovic H, Seitz C, Karakiewicz PI, Roupret M, Rink M, Kluth L, et al. The prognostic role of preoperative serum Creactive protein in predicting the biochemical recurrence in patients treated with radical prostatectomy. Prostate Cancer Prostatic Dis. 2016;19:163-7.

39. Moschini M, Sharma V, Zattoni F, Boorjian SA, Frank I, Gettman MT, Thompson $\mathrm{RH}$, Tollefson MK, Kwon ED, Karnes RJ. Risk stratification of pN+ prostate cancer after radical prostatectomy from a large single institutional series with long-term followup. J Urol. 2016;195:1773-8.

40. Mortezavi A, Sulser T, Robbiani J, Drescher E, Disteldorf D, Eberli D, Poyet C, Baumgartner MK, Seifert HH, Hermanns T. Long-term oncologic outcome of an initial series of laparoscopic radical prostatectomy for clinically localized prostate cancer after a median follow-up of 10 years. Clin Genitourin Cancer. 2016;14:290-7.

41. Mao Y, Li K, Lu L, Si-Tu J, Lu M, Gao X. Overexpression of Cdc20 in clinically localized prostate cancer: relation to high Gleason score and biochemical recurrence after laparoscopic radical prostatectomy. Cancer Biomark. 2016; 16:351-8.

42. Song C, Park S, Park J, Shim M, Kim A, Jeong IG, Hong JH, Kim CS, Ahn H. Statin use after radical prostatectomy reduces biochemical recurrence in men with prostate cancer. Prostate. 2015;75:211-7.

43. Reeves F, Hovens CM, Harewood L, Battye S, Peters JS, Costello AJ, Corcoran NM. Does perineural invasion in a radical prostatectomy specimen predict biochemical recurrence in men with prostate cancer? Can Urol Assoc J. 2015:9:E252-5.

44. Alvin LW, Gee SH, Hong HH, Christopher CW, Henry HS, Weber LK, Hoon TP, Shiong LL. Oncological outcomes following robotic-assisted radical prostatectomy in a multiracial Asian population. J Robot Surg. 2015;9:201-9.

45. Ritch CR, You C, May AT, Herrell SD, Clark PE, Penson DF, Chang SS, Cookson MS, Smith JA Jr, Barocas DA. Biochemical recurrence-free survival after robotic-assisted laparoscopic vs open radical prostatectomy for intermediate- and high-risk prostate cancer. Urology. 2014;83:1309-15.

46. Turker P, Bas E, Bozkurt S, Gunlusoy B, Sezgin A, Postaci H, Turkeri L. Presence of high grade tertiary Gleason pattern upgrades the Gleason sum score and is inversely associated with biochemical recurrence-free survival. Urol Oncol. 2013;31:93-8.

47. Iremashvili V, Pelaez L, Manoharan M, Acosta K, Rosenberg DL, Soloway MS. Tumor focality is not associated with biochemical outcome after radical prostatectomy. Prostate. 2012;72:762-8.

48. Connolly SS, Cathcart PJ, Gilmore P, Kerger M, Crowe H, Peters JS, Murphy DG, Costello AJ. Robotic radical prostatectomy as the initial step in multimodal therapy for men with high-risk localised prostate cancer: initial experience of 160 men. BJU Int. 2012;109:752-9.

49. Busch J, Stephan C, Herold A, Erber B, Kempkensteffen C, Hinz S, Lein M, Weikert S, Miller K, Magheli A. Long-term oncological and continence outcomes after laparoscopic radical prostatectomy: a single-centre experience. BJU Int. 2012;110:E985-90.

50. Berge V, Berg RE, Hoff JR, Wessel N, Svindland A, Karlsen SJ, Eri LM. Five-year progression-free survival in 577 patients operated on with laparoscopic radical prostatectomy for localized prostate cancer. Scand J Urol Nephrol. 2012;46:8-13.

51. Lee SE, Lee WK, Jeong MS, Abdullajanov M, Kim DS, Park HZ, Jeong SJ, Yoon CY, Byun SS, Choe G, Hong SK. Is body mass index associated with pathological outcomes after radical prostatectomy in Korean men? BJU Int. 2011;107:1250-5.

52. Fukuhara $H$, Kume $H$, Suzuki $M$, Fujimura $T$, Enomoto $Y$, Nishimatsu $H$, Ishikawa A, Homma Y. Maximum tumor diameter: a simple independent predictor for biochemical recurrence after radical prostatectomy. Prostate Cancer Prostatic Dis. 2010;13:244-7.

53. Cho IC, Chung HS, Cho KS, Kim JE, Joung JY, Seo HK, Chung J, Park WS, Hong EK, Lee $\mathrm{KH}$. BCl-2 as a predictive factor for biochemical recurrence after radical prostatectomy: an interim analysis. Cancer Res Treat. 2010;42:157-62.

54. Jeon HG, Bae J, Yi JS, Hwang IS, Lee SE, Lee E. Perineural invasion is a prognostic factor for biochemical failure after radical prostatectomy. Int J Urol. 2009;16:682-6.

55. Schroeck FR, Sun L, Freedland SJ, Jayachandran J, Robertson CN, Moul JW. Race and prostate weight as independent predictors for biochemical recurrence after radical prostatectomy. Prostate Cancer Prostatic Dis. 2008;11:371-6.

56. Pavlovich CP, Trock BJ, Sulman A, Wagner AA, Mettee LZ, Su LM. 3-year actuarial biochemical recurrence-free survival following laparoscopic radical prostatectomy: experience from a tertiary referral center in the United States. J Urol. 2008;179:917-21. discussion 921-912
57. Hong SK, Han BK, Chung JS, Park DS, Jeong SJ, Byun SS, Choe G, Lee SE. Evaluation of pT2 subdivisions in the TNM staging system for prostate cancer. BJU Int. 2008;102:1092-6.

58. Shariat SF, Khoddami SM, Saboorian H, Koeneman KS, Sagalowsky Al, Cadeddu JA, McConnell JD, Holmes MN, Roehrborn CG. Lymphovascular invasion is a pathological feature of biologically aggressive disease in patients treated with radical prostatectomy. J Urol. 2004;171:1122-7.

\section{Ready to submit your research? Choose BMC and benefit from:}

- fast, convenient online submission

- thorough peer review by experienced researchers in your field

- rapid publication on acceptance

- support for research data, including large and complex data types

- gold Open Access which fosters wider collaboration and increased citations

- maximum visibility for your research: over $100 \mathrm{M}$ website views per year

At BMC, research is always in progress.

Learn more biomedcentral.com/submissions 